\title{
Seasonal Regional Differentiation of Human Thermal Comfort Conditions in Algeria
}

\author{
Salah Sahabi Abed ${ }^{1}$ and Andreas Matzarakis ${ }^{2}$ \\ ${ }^{1}$ Office National de la Météorologie, Centre Climatologique National, 1, Av. Mohamed Khemisti, BP 153, Dar El Beïda, Algiers, Algeria \\ ${ }^{2}$ Research Center Human Biometeorology, Deutscher Wetterdienst, Stefan-Meier-Str. 4, 79104 Freiburg im Breisgau, Germany
}

Correspondence should be addressed to Salah Sahabi Abed; salah_sahabi@yahoo.com

Received 6 June 2017; Revised 28 August 2017; Accepted 17 September 2017; Published 10 December 2017

Academic Editor: Jorge E. Gonzalez

Copyright (C) 2017 Salah Sahabi Abed and Andreas Matzarakis. This is an open access article distributed under the Creative Commons Attribution License, which permits unrestricted use, distribution, and reproduction in any medium, provided the original work is properly cited.

\begin{abstract}
The thermal conditions of the bioclimate of Algeria are investigated applying especially the physiologically equivalent temperature (PET) seasonal variability of five main Algerian cities representing different climate and geographical conditions: coastal region, highland region, and Sahara zone. The physiologically equivalent temperature (PET) calculated for this study at 12.00 UTC (13.00 local time) is used to emphasize the impacts of climate on human heat stress in different seasonal and regional regimes. This study is important since it is performed for the first time in Algeria using a deterministic approach through the calculation of PET based on the body-atmosphere energy balance using the Munich Energy-Balance Model for Individuals (MEMI). Applying PET is a new feature in assessing the bioclimate of Algeria and serves the touristic and the health sector in particular. For touristic purposes, it is part of the new internationally introduced climate touristic/transfer information scheme (CTIS) enabling the Algerian results to be paled in comparison to other countries. Considering climate change, the study shows as a new feature a significant increase in the number of days with strong and extreme heat stress within the last three decades and discusses the risks and advantages for future tourism in Algeria.
\end{abstract}

\section{Introduction}

Several indices and models have been developed by many researchers to assess the impact of thermal stress due to the combined effects of several meteorological parameters on the human body. To assess the influence of climate on the human body, it is necessary to assess the effects not only of a single parameter but all thermal components, which leads to the human heat balance modeling $[1,2]$.

There is a set of typical applications on the calculation of thermal comfort indices, the standard effective temperature (SET) [3], the Universal Thermal Climate Index (UTCI) [4, 5], the perceived temperature (PT) [6], and the physiologically equivalent temperature (PET) [7-9].

All these thermal indices are well documented and include meteorological and thermophysiological parameters [10]. These thermal indices require as meteorological input air temperature, air humidity, wind speed, and the mean radiant temperature $T_{\mathrm{mrt}}$. The latter combines short- and long-wave radiant fluxes from the sky and the ground hemisphere which impact a human of standing posture with a surface shortwave albedo of $30 \%$ and a long-wave absorptivity of 95\% [11].

The knowledge of thermal bioclimatic conditions could be helpful not only for existing and planned tourism resorts and areas but also in providing information about zones and periods where tourists may be negatively affected by weather and climate conditions [12].

This study uses PET because it is internationally introduced in order to assess the climate for tourism purposes and enables the bioclimate of Algeria to be compared with results from other climates [13-15].

For Algeria, most of bioclimate studies were focused in the sixties and seventies on the establishment of the maps based on ecological and meteorological parameters. These studies were particularly conducted to carry out the relation between climate, vegetation, and geography. These bioclimatic maps were designed to help in planning and implementing agriculture and range development in the Algerian arid zone $[12,16]$. 
The impacts of bioclimate on health for Algeria were developed by Tabet-Aoul [17]. To evaluate the comfort degree, the author used empirical indices adapted to semiarid region and used largely in Tunisia [18] to assess the impact of climate conditions on human health and their use, month by month, for the development of certain diseases, particularly the chronic ones like the asthma and cardiovascular diseases which are directly related to climatic variations.

In the literature, few studies introducing the human thermal comfort in Algeria exist. Most of them are dedicated to the architectural aspects and their impacts on amplifying or reducing thermal stress. On this issue, Ali-Toudert and Mayer [19] studied the dependence of outdoor thermal comfort on street design in Ghardaia (located in central Sahara Desert of Algeria) with emphasis on summer conditions in hot and dry climate. Thermal comfort is assessed by means of PET. The results reveal that the vertical profile and orientation of the urban canyon have a decisive impact on the human thermal sensation at street level, as well as all other design details studied. This is mostly because it especially affects the exposure to direct sun.

Ali-Toudert et al. [20] studied the outdoor thermal comfort in a hot and dry climate in relation to urban geometry in the old Saharan city of Beni Isguen, Algeria. The authors show that the heat stress in a hot-dry climate is very high in unobstructed locations in contrast to sheltered urban sites and the vertical street profile is of prime importance in the resulting thermal sensation in addition to the building material used in this city.

Moreover, the projected increase of the air temperature based on the worst and moderate Intergovernmental Panel on Climate Change (IPCC) emission scenario will have much more important impacts on human stress, particularly in Europe and Mediterranean region, as well as areas in which the tourism industry is crucial for the local economy. The projected amplification of the stressful weather conditions is mainly attributed to the increase in the occurrence of heat waves $[12,13]$. In the same context, the Mediterranean zones experiencing extreme heat stress conditions $\left(\mathrm{PET}>35^{\circ} \mathrm{C}\right)$ will also significantly extend [21].

Being a vulnerable country to climate change, extreme air temperature in Algeria during the mid-century is expected to be higher [22-24].

This increase in air temperatures will consequently affect the human thermal bioclimate. According to the new economic vision of the country giving big importance to the tourism sector, this study could assist decision-makers and planners in elaborating their future strategies according to the national tourism management plan for the Horizon 2025 [25].

The objective of this study is to analyze in a sophisticated way the climate conditions in different regions of Algeria related to health and tourism. These regions are represented through selected cities considered among the most urbanized and populated of the country. Furthermore, physiologically equivalent temperature (PET) is utilized as an indicator to evaluate and explore at different seasons the impacts of the meteorological parameters on the thermal comfort conditions representing different climate regions of Algeria: coastal, inland, and Saharan zones. First, briefly the study area and the main climate characteristics of the selected cities are described and the data used as well as the methodology are outlined. Afterwards, PET annual and seasonal evolution of the five cities is carried out. Next, the analysis and comparison of the annual extreme thermal conditions for each city are presented. In the last section, bioclimate diagrams $[14,15$, 21] are established and analyzed. Main results, outputs, and advantages of the study are discussed in the last section.

\section{Method}

Among the human bioclimatic models, the recently developed "RayMan Pro" is applied. It estimates the radiant fluxes for simple and complex environments based on several parameters, such as air temperature, air humidity, the fraction of cloud cover, date, time of day, and the albedo of the surrounding surfaces [11], and calculates afterwards $T_{\mathrm{mrt}}$ and the physiologically equivalent temperature (PET) $[2,13]$.

The PET index was developed in 1987 by Mayer and Höppe [8]. PET gives an estimation of the thermal sensation and the corresponding heat stress level. It is defined as the air temperature of a closed compartment under typical standard conditions; the heat budget of the human body is balanced with the same skin and core temperature as under the complex outdoor conditions to be assessed [7].

PET is determined based on the above-mentioned four meteorological variables and the two thermophysiological parameters: thermal insulation of clothing that is set at 0.9 clo $\left(1 \mathrm{clo}=0.155 \mathrm{~K} \mathrm{~m}^{2} \mathrm{~W}^{-1}\right)$ and level of human activity that is set at $80 \mathrm{~W}[9,11]$. PET is a measure for the human thermal perception of the environment and of the grade of physiological stress which results from the environments impact. PET accounts for all meteorological variables that influence the human energy balance especially for short- and long-wave radiation. Thus, bioclimatic analyses based on PET show a significantly improved informative value compared to using air temperature alone.

Human parameters influencing PET are usually normalized in the MEMI model because the focus is not on individual human characteristics but on climatic conditions in different environment $[26,27]$. In order to quantify the perception thermal environments by humans, PET threshold values have been developed, indicating different levels of heat stress in the form of a graduated index (Table 1). However, thermal perception describes the subjective sensation of pleasantness, that is, comfort or discomfort to cold and to heat, respectively, and depends not only on the perception of skin temperature but also on that of deep body temperature [28]. The grade of physiological stress refers to any change in the thermal relation between the human body and its environment which, if uncompensated by temperature regulation, would result in hyper- or hypothermia [29]. Deviations of body temperature induced by sustained thermal stress which cannot be fully compensated by temperature regulation result in thermal strain and can additionally cause changes in the state of other nonthermal regulatory systems [29], that is, may cause any health problems. 


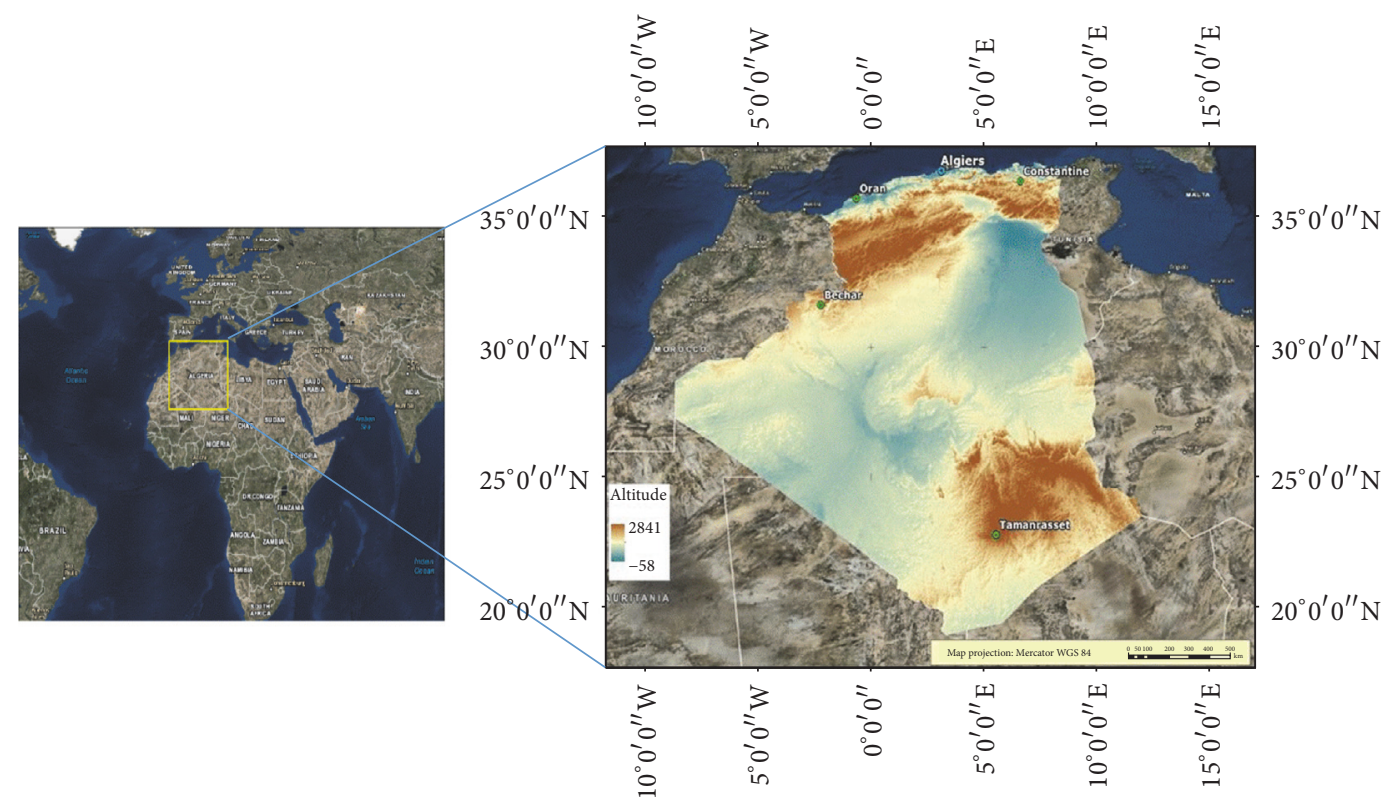

Figure 1: Location of the 5 Algerian cities selected for the study.

TABLE 1: Ranges of physiologically equivalent temperature (PET in ${ }^{\circ} \mathrm{C}$ ) for different grades of thermal perception by humans according to Matzarakis and Mayer [30] with internal heat production, $80 \mathrm{~W}$, and heat transfer resistance of the clothing, 0.9 clo.

\begin{tabular}{lcc}
\hline PET $\left({ }^{\circ} \mathrm{C}\right)$ & Thermal perception & $\begin{array}{c}\text { Grade of } \\
\text { physiological stress }\end{array}$ \\
\hline$<4$ & Very cold & Extreme cold stress \\
$4-8$ & Cold & Strong cold stress \\
$8-13$ & Cool & Moderate cold stress \\
$13-18$ & Slightly cool & Slight cold stress \\
$18-23$ & Comfortable & No thermal stress \\
$23-29$ & Slightly warm & Slight heat stress \\
$29-35$ & Warm & Moderate heat stress \\
$35-41$ & Hot & Strong heat stress \\
$>41$ & Very hot & Extreme heat stress \\
\hline
\end{tabular}

\section{Study Area and Data}

Five important cities from Algeria were selected for this study: Algiers, Oran, Constantine, Béchar, and Tamanrasset (Figure 1). These cities are well distributed over the Algerian territory and present different kind of climate and geography. Localized along the western Mediterranean Sea, Algiers, the capital city, and Oran in the western coastal part of Algeria constitute the most important coastal cities in terms of inhabitants, tourist activities, and economy for the country. This region is of importance not only for its growth rate but most importantly because it is confined between the large Sahara Desert and the Mediterranean Sea and represents a typical semiarid region vulnerable to complete desertification [32]. The existence of various types of climate in Algeria offers to different sites an adequate environment for tourism and other related activity outside the summer season: Constantine in the Northeastern part, Béchar in the Northwest of the Sahara, and Tamanrasset in the extreme south are some of privileged destinations for national and international tourists. The type of the climate of each city based on the criteria of KöppenGeiger classification [31] is given in Table 2.

Within the temperate zone, the north of Algeria enjoys a Mediterranean-style climate, although the diversity of the relief provides sharp contrasts in air temperatures. Located in the thin coastal strip, the climate of Oran and Algiers is typically Mediterranean, with mild rainy winters and hot sunny summers. The rains are scarcer particularly in the western part. August is the warmest month with an average maximum air temperature reaching $+32.9^{\circ} \mathrm{C}$ for Algiers and $+32.3^{\circ} \mathrm{C}$ for Oran. In winter, average air temperatures are around $+16^{\circ} \mathrm{C}$ for Algiers and $+15^{\circ} \mathrm{C}$ for Oran but can drop down, with snow common in certain highland regions surrounding these cities, where the minimum average temperatures are observed in January with about less than $+6.0^{\circ} \mathrm{C}$. The rainiest month is November with $96.6 \mathrm{~mm}$ for Algiers and $64.1 \mathrm{~mm}$ for Oran (Figures 2(a) and 2(b)). The climate of both cities is defined as Csa according to Köppen-Geiger classification.

The climate of Constantine (Köppen-Geiger classification, Csa) located at approximately $700 \mathrm{~m}$ asl in the northeast highlands with an important number of inhabitants is considered as transitional of the northern hills and mountains, a little more continental, and moderately rainy. July and August are the hottest months (the average maximum air temperature is $+34.5^{\circ} \mathrm{C}$ ). January is the coldest month in Constantine with an average minimum air temperature of $+3.4^{\circ} \mathrm{C}$ and December is the rainiest one with an average of $71 \mathrm{~mm}$ (Figure 2(c)).

In the area around Oran, where mountains form a barrier against rain-carrying winds, the rainfall is less abundant. The average annual total rainfall in Oran is $356.1 \mathrm{~mm}$, where in 


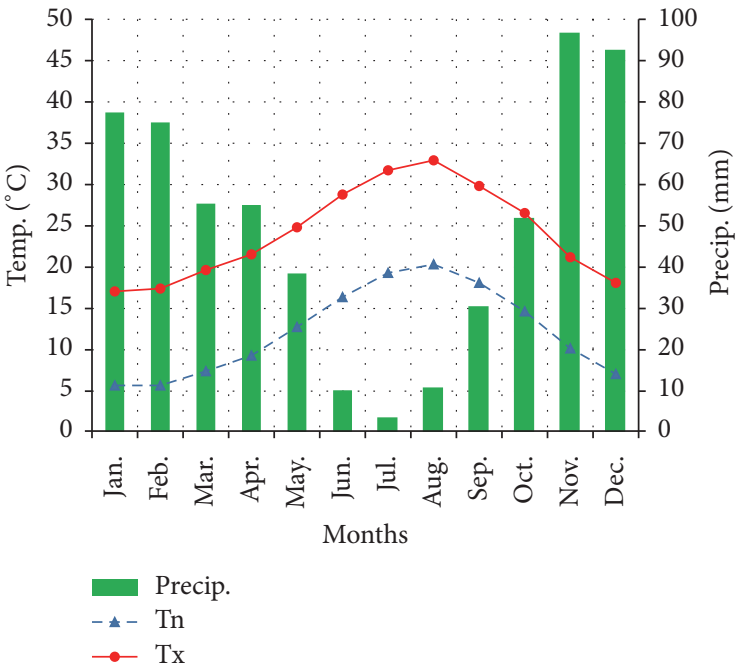

(a) Algiers

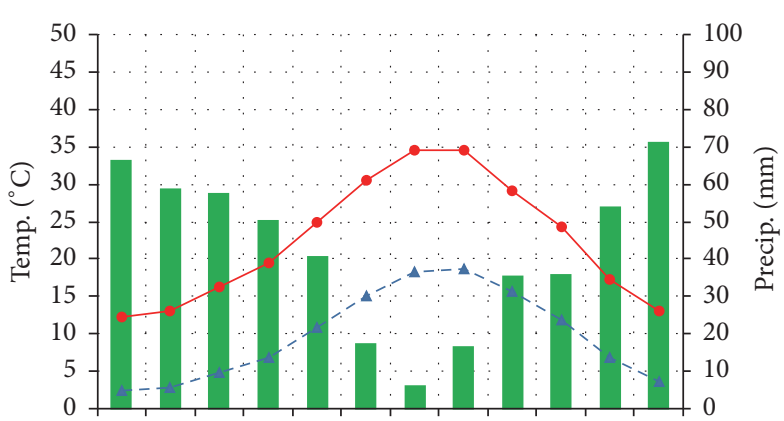

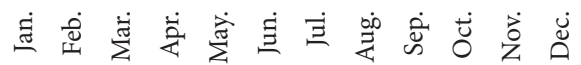

Months

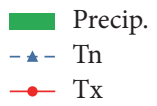

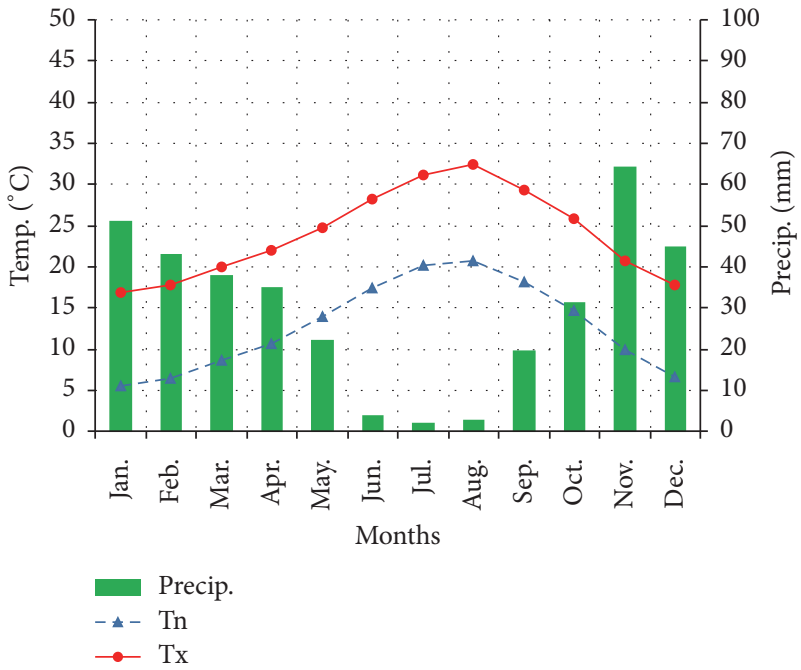

(b) Oran

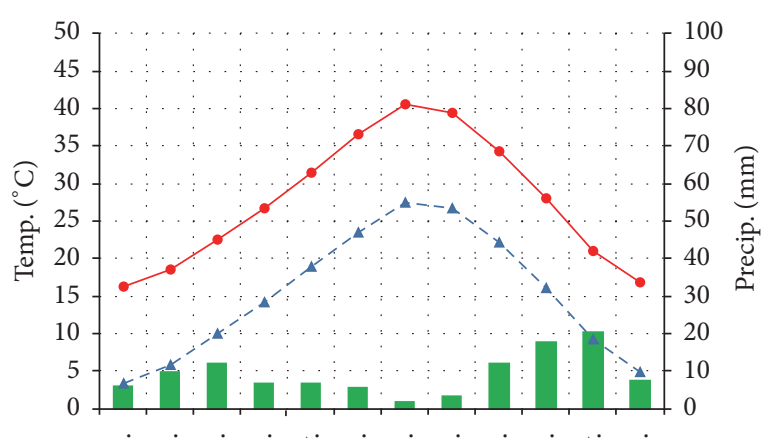

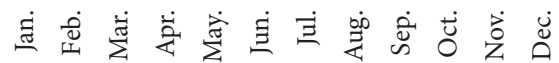

Months

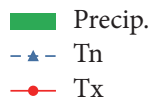

(c) Constantine

(d) Béchar

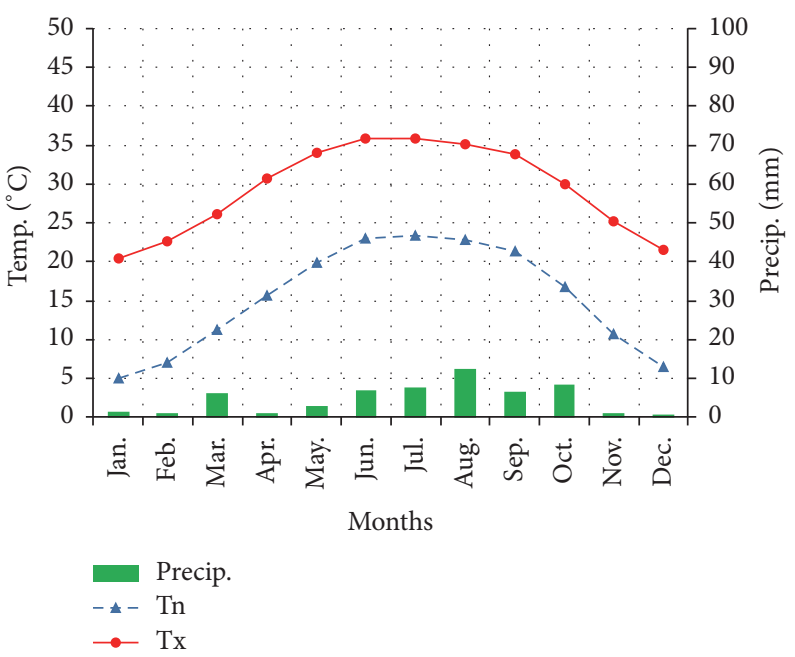

(e) Tamanrasset

Figure 2: Climate diagram of the 5 Algerian cities for the period of 1986-2015. "Tx" is the mean monthly maximum air temperatures (red solid line); "Tn" is the mean monthly minimum air temperatures (blue dashed line); and "Precip." is the mean monthly precipitation amount in $\mathrm{mm}$ (green bars). 
TABLE 2: Geographical coordinates and climate classification of the 5 cities according to Köppen-Geiger climate classification criteria [31].

\begin{tabular}{lcccc}
\hline City & Latitude (north) & Longitude & Altitude $(\mathrm{m})$ & Köppen and Geiger's climate classification \\
\hline Algiers & $36^{\circ} 41^{\prime}$ & $03^{\circ} 13^{\prime} \mathrm{E}$ & 29 & Csa \\
Oran & $35^{\circ} 38^{\prime}$ & $00^{\circ} 36^{\prime} \mathrm{W}$ & 91 & Csa \\
Constantine & $36^{\circ} 16^{\prime}$ & $06^{\circ} 37^{\prime} \mathrm{E}$ & 692 & Csa \\
Béchar & $31^{\circ} 39^{\prime}$ & $02^{\circ} 15^{\prime} \mathrm{W}$ & 816 & Bwh \\
Tamanrasset & $22^{\circ} 47^{\prime}$ & $05^{\circ} 31^{\prime} \mathrm{E}$ & 1377 & Bwh \\
\hline
\end{tabular}

Algiers it is $595.1 \mathrm{~mm}$. In the Constantine region, prevailing winds are westerly. They are northerly in winter and easterly and northeasterly in summer, resulting in a general increase in precipitation from September to December and a decrease from January to August; the average rainfall total amount in Constantine is $509.6 \mathrm{~mm}$.

Located in the northwestern part of the desert at more than $800 \mathrm{~m}$ asl, Béchar is one of the most populated cities of the northwest of the Algerian Sahara. Béchar has a hot desert climate (Köppen climate classification, BWh) with extremely hot summers and warm winters despite the high elevation. There is very little rain throughout the year. In this region, midday desert temperatures can be hot year round. After sunset, however, the clear, dry air permits rapid loss of heat, and the nights are cool to chilly. Enormous daily ranges in temperature are recorded.

The climate in Béchar is characterized by a hottest and driest summer season (July and August), where the average maximum air temperature exceeds $+40^{\circ} \mathrm{C}$ in July. Nights in Béchar are often cold and in winter temperatures can dip below freezing.

Experiencing a severe and dry climate, with only $20.4 \mathrm{~mm}$, November is considered as the rainiest month in Béchar (Figure 2(d)).

The city of Tamanrasset at the extreme south of the Sahara at approximately $1400 \mathrm{~m}$ asl has a very salubrious climate and is dry and hyperarid (Köppen climate classification, BWh) and sunny all year round and is tempered by the altitude: in winter it is cold at night, while the days are mild. Tamanrasset is considered as one of the coldest points in the Sahara; its climate is less rigorous than the surrounding region. Locally, the maximum air temperature exceeds rarely $+36^{\circ} \mathrm{C}$. Because of the rarity of clouds, the air temperature drops to $+5^{\circ} \mathrm{C}$ in the winter (January). Influenced sporadically by the extreme offshoots of the African monsoon, which bring some cloudiness and occasional downpours, August is the rainiest month in Tamanrasset with only $12 \mathrm{~mm}$ as average total rainfall (Figure 2(e)).

To study the human bioclimate conditions for the selected cities, daily recorded meteorological variables of these five cities and for the time period of 1986-2015 are used, which are obtained from the Algerian National Meteorological Office network belonging to the World Meteorological Organization (WMO) regional basic synoptic network. The instruments used to observe and measure these parameters meet therefore the WMO requirements and standards. These weather stations are located at the airports in the suburbs of the cities.

All meteorological data used in the study are homogenized and quality-controlled using HOMER software $[33,34]$.
To evaluate the grade of physiological stress at the extreme climate conditions of the day, the required daily data for the calculation of PET using the RayMan Pro model [2, 13] concerns the observed air temperature, wind speed, relative humidity, and cloud cover as a proxy value for the global radiation at $12.00 \mathrm{UTC}$ (13.00 local time). Wind velocity is reduced from synoptic station measure at $10 \mathrm{~m}$ to $1.1 \mathrm{~m}$ height considering the effects of wind on the gravity center of human body [11].

This reduction is conducted according to the following formula [35-42]:

$$
\mathrm{WS}_{1.1}=\mathrm{WS}_{h} *\left(\frac{1.1}{h}\right)^{\alpha}
$$

where $\alpha=0.18+0.12 * Z_{0}$,

where $\mathrm{WS}_{h}$ is the wind speed $\left(\mathrm{ms}^{-1}\right)$ at a height of $h(10 \mathrm{~m})$, " $\alpha$ " is an empirical exponent, depending on the surface roughness, and $Z_{0}$ is the roughness length [36]. In our case, $Z_{0}=0.005$, since the study sites (meteorological stations) could be considered as sites with groundcover of low grass.

\section{Results}

Seasonal and annual variation time series of PET calculated at a daily temporal resolution for the five Algerian cities during the period of 1986-2015 are individually plotted (Figures 3(a)-3(e)). PET calculated for Algiers and Oran during the winter season (December-February) ranges between 15 and $18^{\circ} \mathrm{C}$ (Figures 3(a) and 3(b)); the climate conditions are then the most comfortable during this season. The climate is mild in winter in Algiers, Oran, and Constantine (Figure 3(c)). As Constantine is on the Tell Atlas mountain chain, forming a natural barrier between the Mediterranean and the Sahara which is wetter in winter because it receives more easily humid winds from the sea, particularly when cold air masses prevail, bringing occasionally snow and frost, the PET could drop up to $11.6^{\circ} \mathrm{C}$ (2003) without exceeding $16.1^{\circ} \mathrm{C}$ (i.e., 2008). The maximum of PET was recorded in the early 2000s for these three cities. In winter, the warmest area is the far south of the Sahara; therefore the PET during this season is greater in Tamanrasset than in Béchar. PET in Béchar (Figure 3(d)) and Tamanrasset (Figure 3(e)) in the winter season varies, respectively, between 20 and $23^{\circ} \mathrm{C}$; their bioclimate can be consequently qualified as comfortable to slightly warm.

During the spring season (March-May), Oran and Algiers exhibit upward shifting in PET since 1997. The average values are since then fluctuating around $23^{\circ} \mathrm{C}$, thus generating 

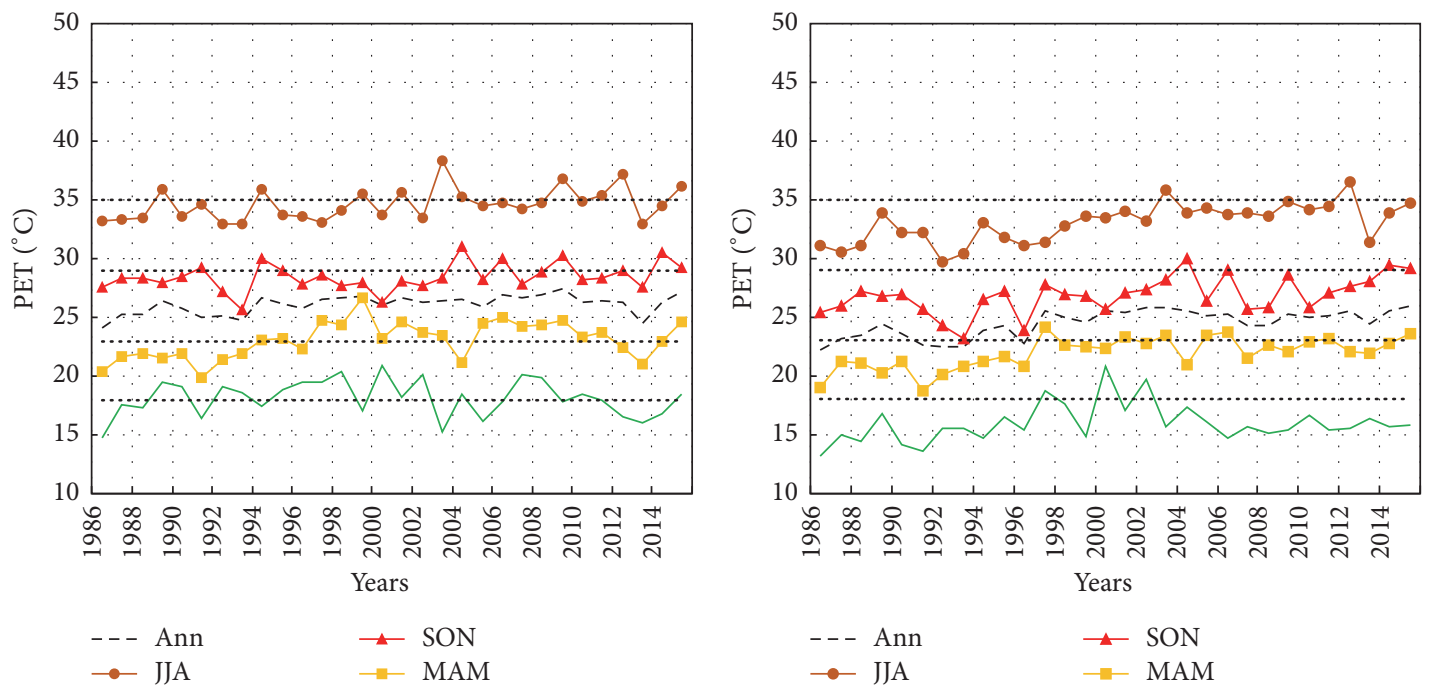

(a) PET: Algiers

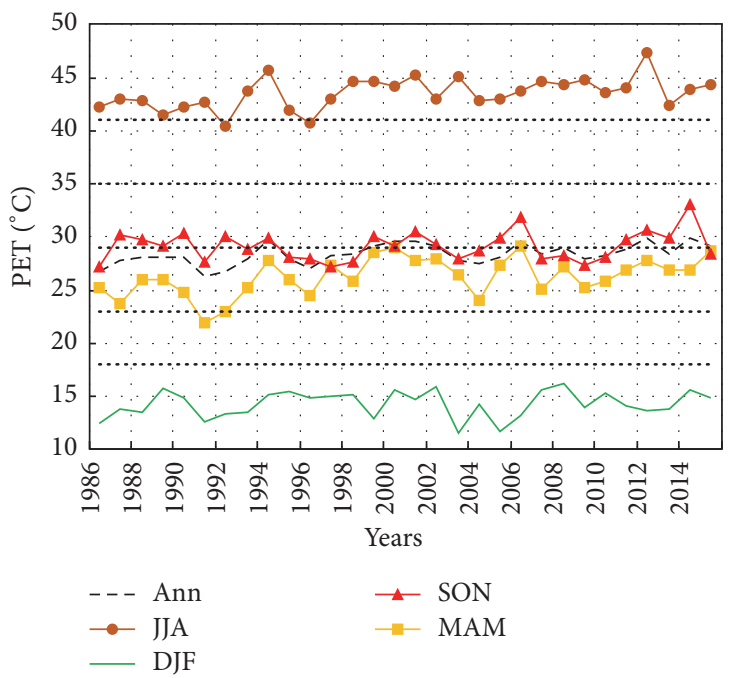

(b) PET: Oran

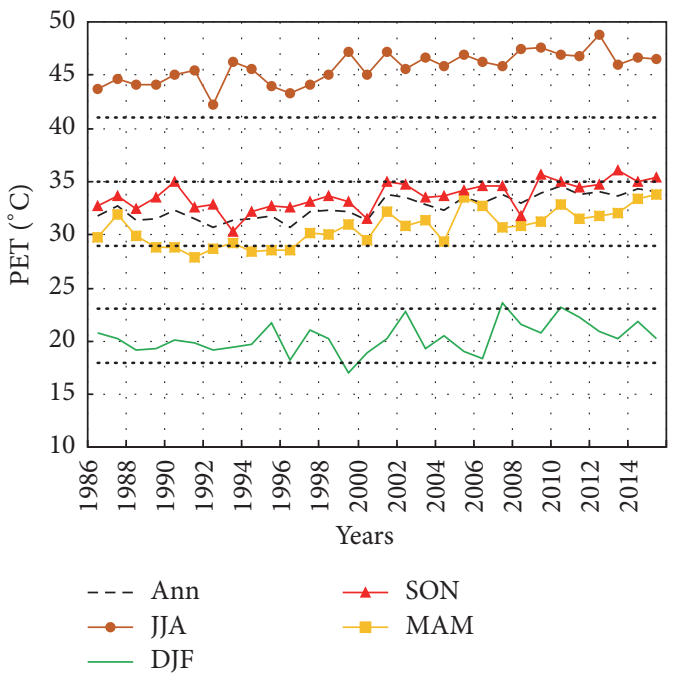

(c) PET: Constantine

(d) PET: Béchar

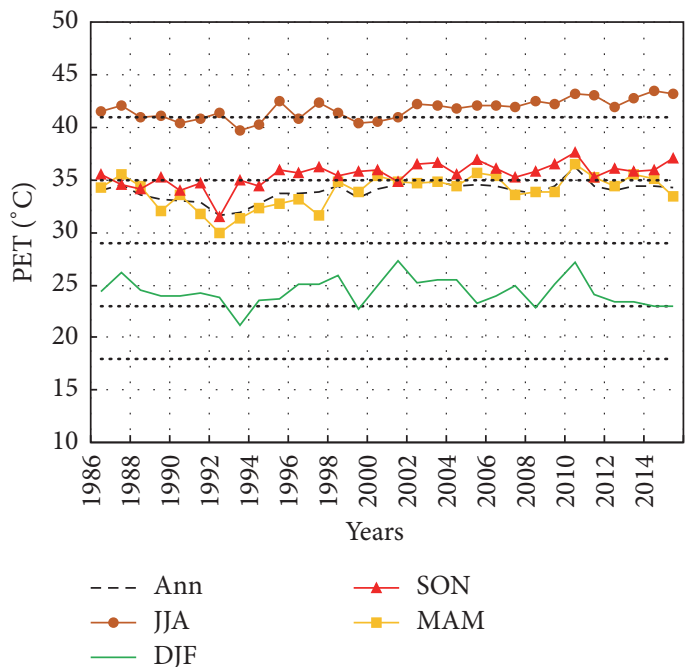

(e) PET: Tamanrasset

Figure 3: Annual and seasonal evolution time series of PET for the 5 Algerian cities for the period of 1986-2015: "Ann" (dashed curve line) is the annual PET variation, "DJF" concerns the winter season (December to February), "MAM" concerns the spring (March to May), "JJA" concerns the summer (June to August), and "SON" concerns the autumn (September to November). Horizontal straight dotted lines indicate the PET limit thresholds classes mentioned in Table 1. 
a slight heat stress bioclimate. During the same season, PET for Constantine varies around $27^{\circ} \mathrm{C}$. In this city and from 2000, a significant upward trend is observed. Although in Béchar and Tamanrasset PET range $\left(29\right.$ to $\left.35^{\circ} \mathrm{C}\right)$ is quite high, both cities offer a bioclimate of moderate and infrequently also strong heat stress. In Algiers and Oran and since 2004 with continuous highest PET values, the climate conditions during the fall season (September-November) emphasize situations of moderate heat stress. These two cities observe an average PET equivalent to $27^{\circ} \mathrm{C}$, whereas Constantine approximates $30^{\circ} \mathrm{C}$ during this season. The Saharan stations approach an average PET of $35^{\circ} \mathrm{C}$ since 2000 for Béchar and since 1995 for Tamanrasset.

Basically, in spring and autumn, the weather conditions in the north of the country emphasize a slight comfortable-tomoderate climate conditions, while in the south a moderateto-strong heat stress bioclimate is generally observed.

During the summer period (June-August), bioclimate of Algiers is thermally perceived as hot and results in strong heat stress (PET partly exceeds $35^{\circ} \mathrm{C}$ ). Air temperatures in this season in Algiers are higher, though humidity can make the summer heat uncomfortable. The maximum PET value of $38^{\circ} \mathrm{C}$ is recorded in summer of 2003 and coincides with the severe heat wave that hit Europe [43]. The PET variation is quasi-stable over the period of the study. Nevertheless, in Oran, the largest values of PET in the summer appear since 2003 with a maximum observed in $2012\left(37^{\circ} \mathrm{C}\right)$.

Despite its position in the northern part of the country, Constantine as an inland zone does not seem to offer a favorable environment in the summer. Therefore, the summer is as hot as on the coastal zone, but the humidity is lower; besides, it is hotter during the day and cooler at night. The time series of PET of this city shows most of values exceeding $41^{\circ} \mathrm{C}$ (with a maximum of $47.4^{\circ} \mathrm{C}$ recorded in 2012).

During the summer season, the climate conditions are very unfavorable in Tamanrasset and more particularly in Béchar. The hottest area lies generally between $24^{\circ}$ and $30^{\circ}$ $\mathrm{N}$, because the far south part of the Algerian Sahara is sporadically under the aforementioned marginal influence of the African monsoon. This phenomenon is also responsible for the decrease in the amount of sunshine in summer in this region (10 hours per day, compared with 12 hours in the central and northern regions of the Sahara). The effect of altitude plays also a primary role in reducing the intensity of PET in Tamanrasset. During the summer season, the minimum PET was observed in $1992\left(42.2^{\circ} \mathrm{C}\right)$ for Béchar and in $1993\left(39.7^{\circ} \mathrm{C}\right)$ for Tamanrasset, while the maximum was observed in $2012\left(48.8^{\circ} \mathrm{C}\right)$ for Béchar and in $2014\left(43.4^{\circ} \mathrm{C}\right)$ for Tamanrasset.

In general, in Algeria, the coastal cities along the Mediterranean Sea remain the most comfortable sites during the summer and spring seasons. The air is quite humid; the sea breezes occur most often during these seasons because of the greater temperature differences between the ocean and nearby land, offering much more favorable conditions for human comfort than the other parts of the country. However, since 2003, Oran and Algiers have been experiencing similar bioclimate conditions during the summer season.

\section{Occurrence Evolution of Annual Hot $\left(\right.$ PET $\left.>35^{\circ} \mathrm{C}\right)$ and Very Hot $\left(\right.$ PET $\left.>41^{\circ} \mathrm{C}\right)$ Days}

The change in the seasonal variability of PET along the period of 1986-2015 is also followed by an increase in the yearly occurrence of hot and very hot days, causing strong and extreme heat stress for all zones (Figures 4(a)-4(e)). A nonparametric Mann-Kendall test and Sen's slope estimates [44] were used to determine the statistical significance and magnitude of the calculated trend in number of days with PET $>35^{\circ} \mathrm{C}$ and PET $>41^{\circ} \mathrm{C}$ for each city. On running MannKendall's test on annual occurrence evolution of hot (PET > $\left.35^{\circ} \mathrm{C}\right)$ and very hot $\left(\mathrm{PET}>41^{\circ} \mathrm{C}\right)$ days, the results in Table 3 are obtained from the five stations' data.

Indeed, the number of days of PET exceeding $35^{\circ} \mathrm{C}$ threshold has significantly increased between 1986 and 2015 . The number of hot days $\left(\mathrm{PET}>35^{\circ} \mathrm{C}\right)$ has significantly augmented (at $\alpha=0.05$ significance level) in Algiers with a rate of +9 days/decade (10 years) (Figure 4(a)), as well as in Oran (Figure 4(b)) and Constantine (Figure 4(c)), both, respectively, with +12 days/decade and +7 days/decade, and finally Béchar with +14 days/decade (Figure 4(d)). A similar trend is also observed for Tamanrasset with +7 days/decade (at $\alpha=0.05$ significance level) (Figure 4(e)).

The number of hot days (PET $\left.>35^{\circ} \mathrm{C}\right)$ per year in Oran was around 22 in 1986, reaching 69 in 2015, whereas in Algiers it was about 60 in nineties, where the maximum (100 days) was observed in 2009. In Constantine, the number of days with strong heat stress ranged from 113 in 1986 and about 133 days per year in 2015; it was close to 150 from 1986 to 2000 to reach 192 in 2015 in Béchar. For Tamanrasset, this class has been since 2000 approaching 200 days/year.

The number of days with very hot thermal perception $\left(\mathrm{PET}>41^{\circ} \mathrm{C}\right)$ is significantly increasing (statistically at $\alpha=$ 0.05 level of significance). For the whole five cities (Figures 4(a)-4(e)), the discomfort conditions frequency is particularly growing in the two desert cities, with an average of 20 days per decade in Tamanrasset and 9 days per decade in Béchar. The growing rate for PET $>41^{\circ} \mathrm{C}$ was less important in Constantine with about 4 days/decade and weaker in Algiers and Oran with only 2 days/decade.

The occurrence of extreme heat stress $\left(\mathrm{PET}>41^{\circ} \mathrm{C}\right)$ for the coastal region fluctuated around 20 days or less during the study period for Algiers and Oran. It was gradually increasing and varying from 50 in nineties to about 100 days during the last years in Constantine as well as in Tamanrasset.

In Béchar, the frequency of very hot days was more pronounced (100 to 130 days).

The climate severity is mostly responsible for the large difference of the occurrence of the extreme heat stress (PET $>41^{\circ} \mathrm{C}$ ) observed between the northern zone and the Saharan one.

\section{PET Bioclimate Diagrams for the Selected Cities}

To analyze the general daily bioclimate conditions based on PET values calculated at 12.00 UTC for the period from 


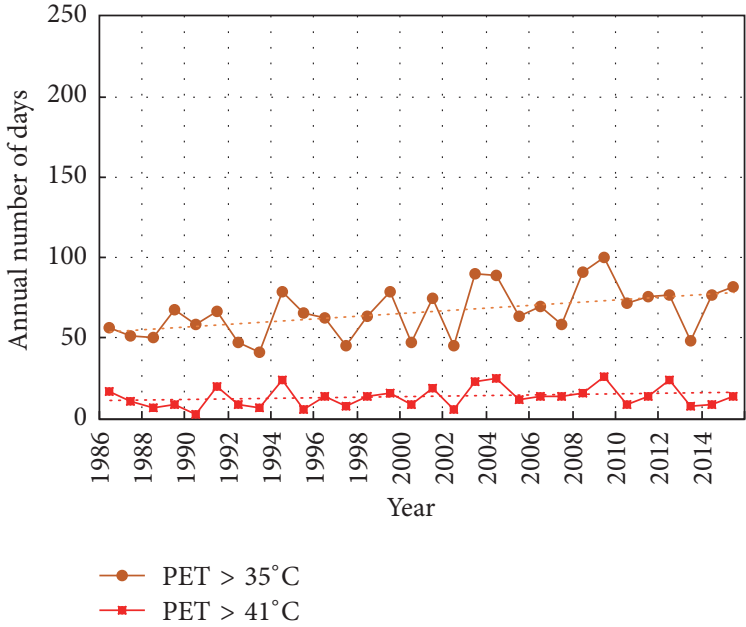

(a) Algiers

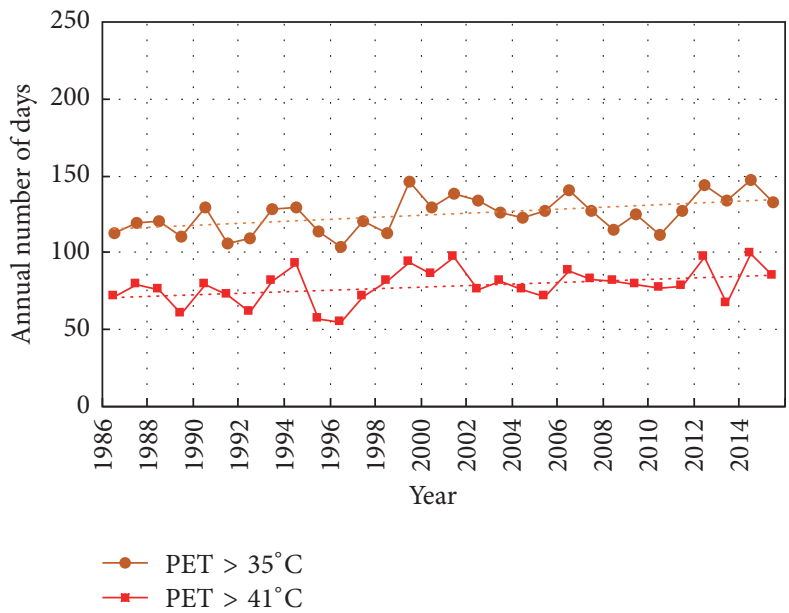

(c) Constantine

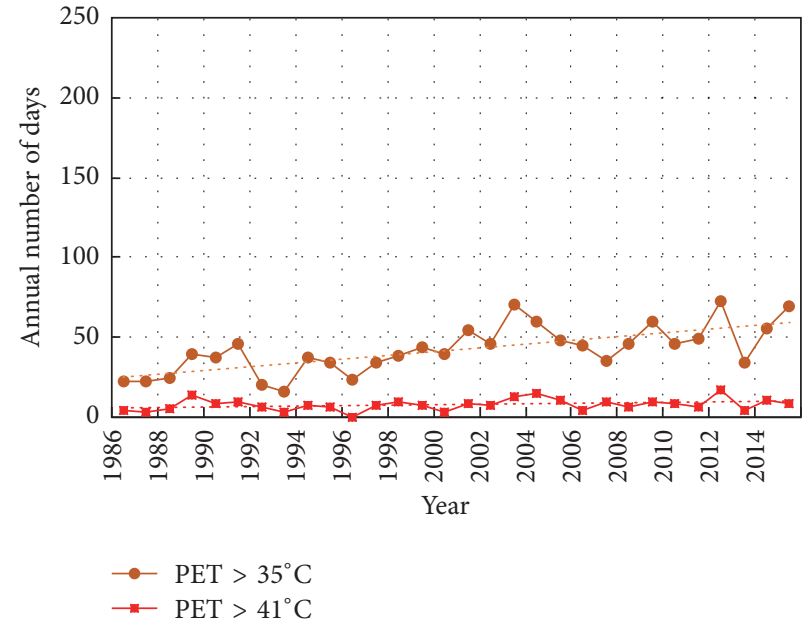

(b) Oran

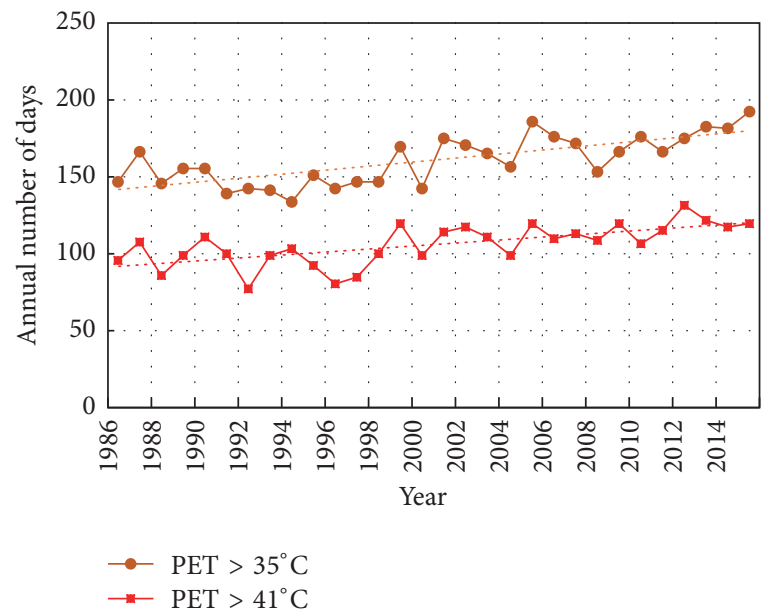

(d) Béchar

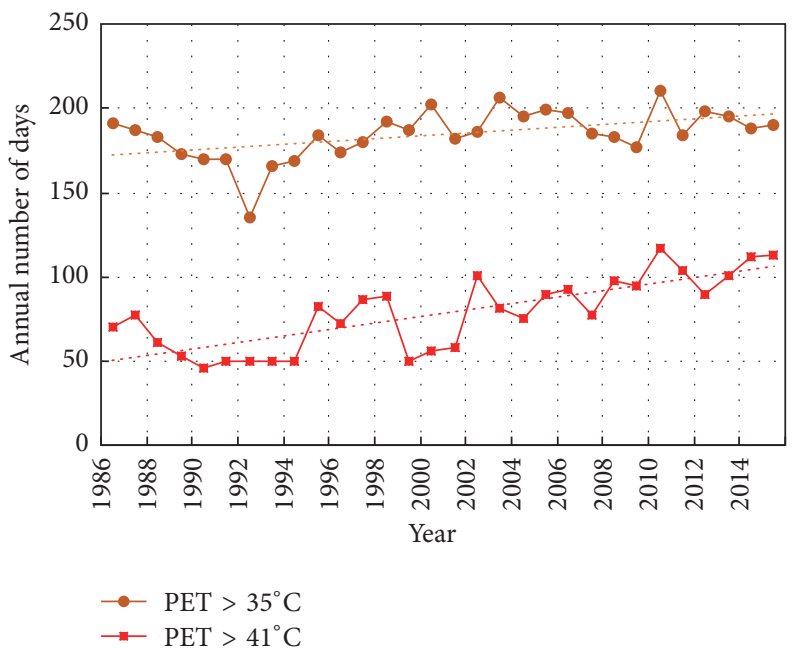

(e) Tamanrasset

FIgURE 4: Evolution of the annual number of days in each city (solid lines) with $\mathrm{PET}>35^{\circ} \mathrm{C}$ and $\mathrm{PET}>41^{\circ} \mathrm{C}$ for the period of $1986-2015$ associated with their respective linear trend lines (dotted). 
TABLE 3: Annual occurrence evolution of hot $\left(\mathrm{PET}>35^{\circ} \mathrm{C}\right)$ and very hot $\left(\mathrm{PET}>41^{\circ} \mathrm{C}\right)$ days. Mann-Kendall's trend test results.

\begin{tabular}{|c|c|c|c|c|c|c|}
\hline Station & Parameter & Mann-Kendall stat $(S)$ & var. $(S)$ & Kendall's tau & $P$ value & $\alpha$ \\
\hline \multirow{2}{*}{ Algiers } & $\mathrm{PET}>35^{\circ} \mathrm{C}$ & 143.000 & 3135.667 & 0.331 & 0.011 & 0.05 \\
\hline & $\mathrm{PET}>41^{\circ} \mathrm{C}$ & 69.000 & 3091.667 & 0.164 & 0.221 & 0.05 \\
\hline \multirow{2}{*}{ Oran } & $\mathrm{PET}>35^{\circ} \mathrm{C}$ & 225.000 & 3126.333 & 0.525 & 0.000 & 0.05 \\
\hline & $\mathrm{PET}>41^{\circ} \mathrm{C}$ & 96.000 & 3098.667 & 0.229 & 0.088 & 0.05 \\
\hline \multirow{2}{*}{ Constantine } & $\mathrm{PET}>35^{\circ} \mathrm{C}$ & 144.000 & 3134.000 & 0.334 & 0.011 & 0.05 \\
\hline & $\mathrm{PET}>41^{\circ} \mathrm{C}$ & 116.000 & 3128.667 & 0.270 & 0.040 & 0.05 \\
\hline \multirow{2}{*}{ Béchar } & $\mathrm{PET}>35^{\circ} \mathrm{C}$ & 223.000 & 3130.333 & 0.519 & 0.000 & 0.05 \\
\hline & $\mathrm{PET}>41^{\circ} \mathrm{C}$ & 210.000 & 3121.333 & 0.491 & 0.000 & 0.05 \\
\hline \multirow{2}{*}{ Tamanrasset } & $\mathrm{PET}>35^{\circ} \mathrm{C}$ & 144.000 & 3136.667 & 0.333 & 0.011 & 0.05 \\
\hline & $\mathrm{PET}>41^{\circ} \mathrm{C}$ & 258.000 & 3122.000 & 0.602 & 0.000 & 0.05 \\
\hline
\end{tabular}

1 January 1986 to 31 December 2015, individual bioclimate diagrams were established for each city including 10-day interval frequency classes of thermophysiological stress levels for PET according to Matzarakis and Mayer [30]. In order to evaluate the thermal stress for the period of the study, Figures 5(a)-5(e) present the cumulated relative frequencies for PET values within the 9 classes of thermal perception according to Table 1.

PET occurrence patterns of Algiers (Figure 5(a)) and Oran (Figure 5(b)) are typically Mediterranean (at low altitude). The lowest PET values are ranging from 8 to $13^{\circ} \mathrm{C}$ (cool thermal perception). In Algiers, from the winter season (December-February) till the first decade of March, 40\% of the days with PET $<18^{\circ} \mathrm{C}$ (slight cold to extreme cold stress classes) are recorded. The remaining days in this season belong to the comfort class.

However, more than $60 \%$ of the days with PET $>35^{\circ} \mathrm{C}$ (hot and very hot days) are observed for the period from end of July to end of August. More than $40 \%$ would extend the period from the beginning of July to the beginning of September and more than $20 \%$ to the period from end of June to mid of September.

In Oran, $60 \%$ or more of the days are of cool to slightly cool thermal perception during the whole winter season up to the beginning of March. The remaining days are classified as comfortable to slightly warm (Figure 5(b)). In the summer, the strong heat stress conditions $\left(\mathrm{PET}>35^{\circ} \mathrm{C}\right)$ are mainly observed in August, with more than $80 \%$ of days observed in the beginning of August and 60 to near $67 \%$ of the rest days of this month. Oran city does not exhibit very hot thermal perception class. A strong heat stress seems to last longer in Algiers than in Oran.

As an inland city and due to the continental and altitude effect, Constantine is the only city that exhibits the cold stress class $\left(\mathrm{PET} \leq 4^{\circ} \mathrm{C}\right.$ ) in winter (Figure $5(\mathrm{c})$ ), however, with less than $5 \%$ of the days. More than 50 to less than $95 \%$ of the days with moderate cold to slight cold stress classes are recorded from the end of November to the beginning of March in this city.

Days with very hot thermal perception $\left(\mathrm{PET}>41^{\circ} \mathrm{C}\right.$ ) dominate the whole summer in Constantine with more than $70 \%$ during the 3 rd decade of June to $100 \%$ of the days in the end of July and more than $80 \%$ in August. However, more than $75 \%$ of the days with $\mathrm{PET}>35^{\circ} \mathrm{C}$ (hot and very hot days) are observed during the first two decades of September.

In Béchar, 10 to less than $50 \%$ of days with $13<\mathrm{PET}<$ $18^{\circ} \mathrm{C}$ (slightly cool thermal perception) are observed during the winter season (December-February). The comfortable thermal perception conditions with $18^{\circ} \mathrm{C}<\mathrm{PET}<23^{\circ} \mathrm{C}$ in this region would extend in the period from the end of November to the beginning of March with a percentage of days ranging from more than $35 \%$ to less than $65 \%$. However, $100 \%$ of the days with $\mathrm{PET}>35^{\circ} \mathrm{C}$ (hot and very hot days) are observed for the period from mid of June to mid of September, where the total of days from mid-July to mid-August are with PET > $41^{\circ} \mathrm{C}$ (very hot).

Thermal conditions in Tamanrasset are relatively less rigorous than in Béchar (Figure 5(e)) since the frequency of days with $\mathrm{PET}>41^{\circ} \mathrm{C}$ (very hot) is less important; in this city, more than $90 \%$ of the days with PET ranging from $18^{\circ} \mathrm{C}$ and $29^{\circ} \mathrm{C}$ (comfortable to slightly warm) are observed during the winter season. However, $100 \%$ of days with PET $>35^{\circ} \mathrm{C}$ (hot and very hot days) are recorded from the end of May to the beginning of September.

\section{Discussion}

The annual occurrence of the hot and very hot days corresponding to $\mathrm{PET}>35^{\circ} \mathrm{C}$ and $\mathrm{PET}>41^{\circ} \mathrm{C}$ for the different selected stations representing different types of climates in Algeria shows a significant positive trend since 1986. With 20 days per decade (10 years) as an increase rate for the extreme heat stress, Tamanrasset bioclimatic conditions are rather becoming more and more unfavorable particularly in the summer season. Algiers, even as a coastal city, is experiencing a significant increase of the days of very hot thermal perception (PET $>41^{\circ} \mathrm{C}$ ) with 6 days per decade.

Being a continental city, Constantine's extreme climate conditions are more pronounced. The amplitude range of air temperatures is more important. Located at the transition zone between the Sahara and the littoral, the maximum air temperatures in Constantine during the summer are higher, contributing to the elevation of the grade of physiological stress to the extreme level $\left(\mathrm{PET}>41^{\circ} \mathrm{C}\right)$.

A research study on adaptive thermal comfort in Constantine was undertaken in naturally ventilated university 

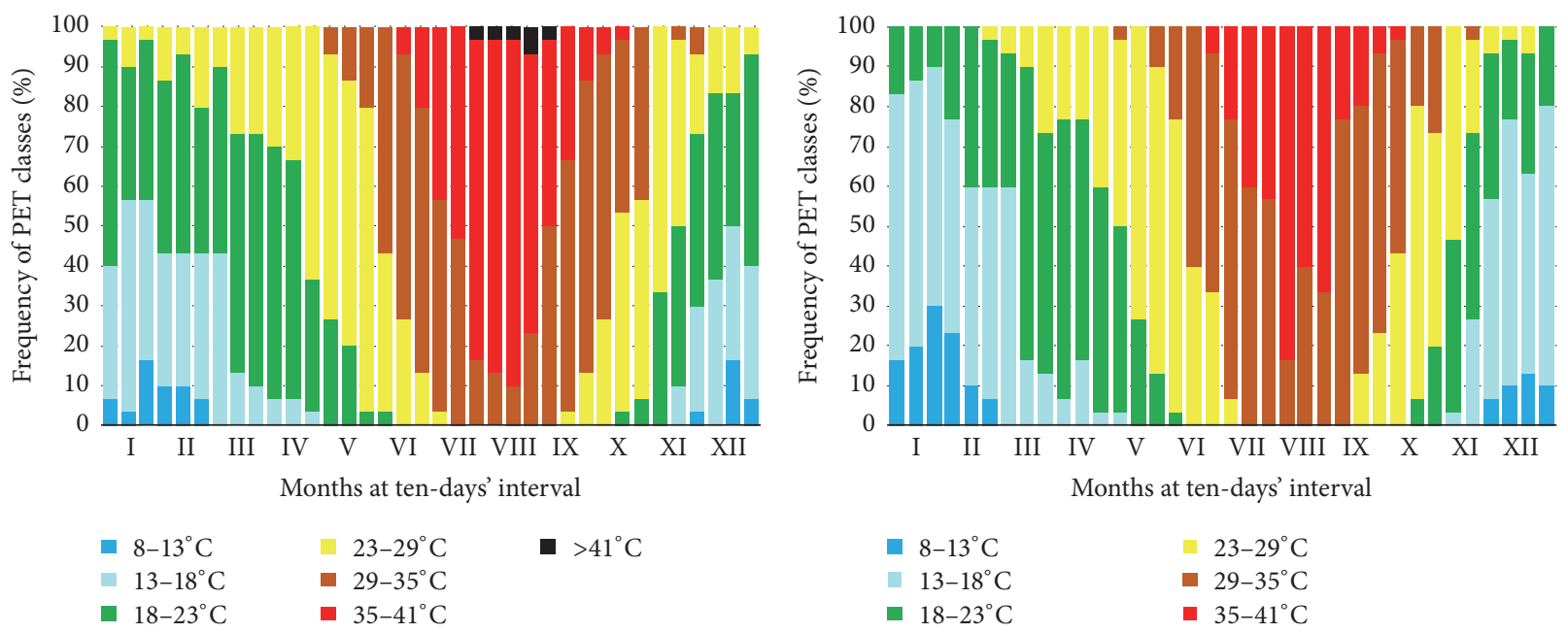

(a) PET: Algiers

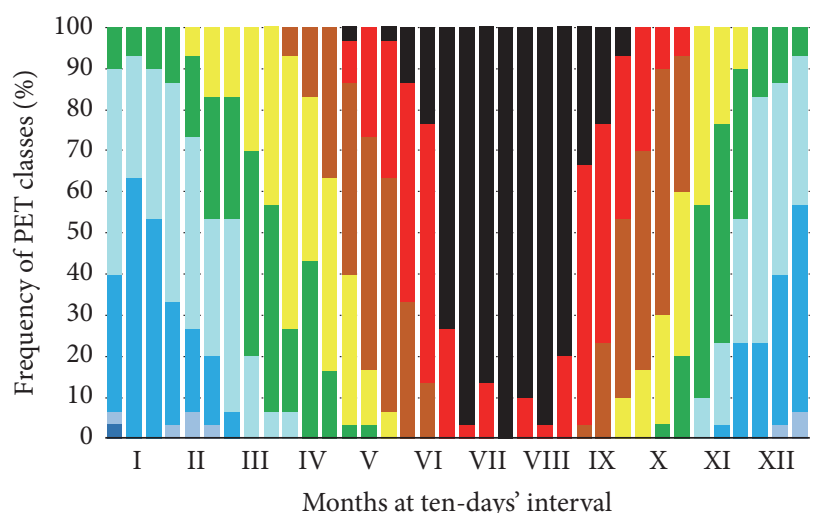

(b) PET: Oran

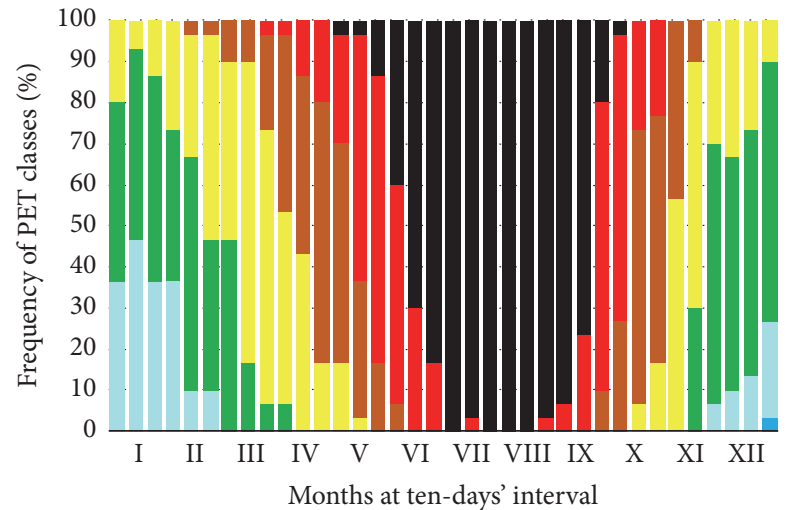

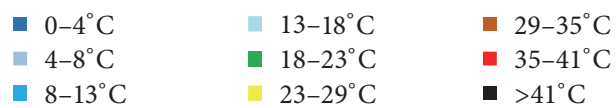

(c) PET $\left({ }^{\circ} \mathrm{C}\right)$ : Constantine

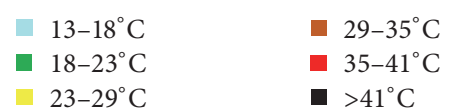

(d) PET: Béchar

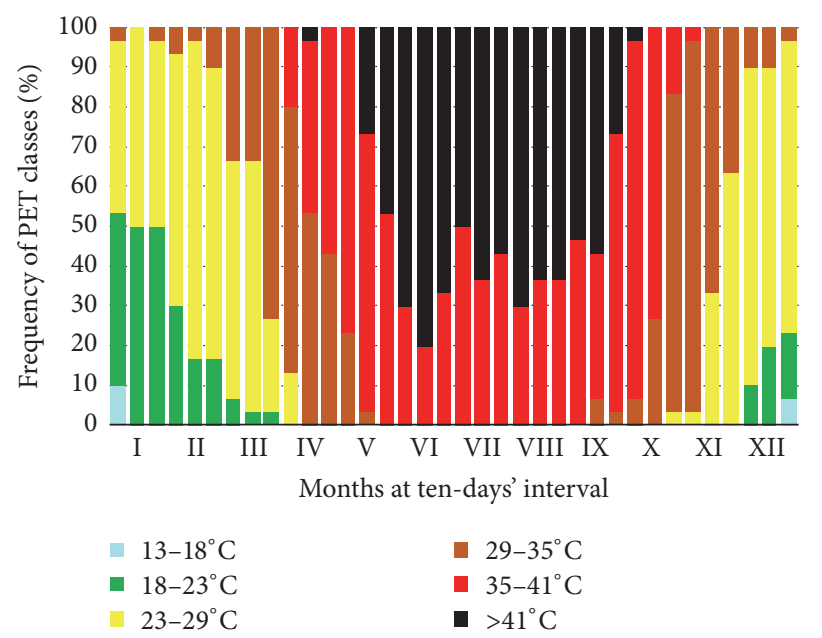

(e) PET: Tamanrasset

FIGURE 5: Bioclimatic diagram for the 5 cities for the period of 1986-2015; frequencies (\%) of the nine PET classes for 10-day period of the mean year. 
classrooms in hot and dry climates to assess the thermal comfort of students [45]. The study showed that there is not a single neutral temperature for the same population; it changes through the seasons. The university residents prefer the warm thermal sensations in winter, while the cold sensations are unacceptable during this period. The Predicted Mean Vote (PMV) obtained in this study seems to be overestimating the thermal sensation in winter and underestimating it in warm period. However, the authors concluded that the ASHRAE scale (ASHRAE: American Society of Heating, Refrigerating and Air conditioning Engineers) overestimates the dissatisfaction of the occupants of these classrooms because a large percentage of people who voted "hot" or "cold" found these thermal sensations acceptable [45]. In our study, Constantine was the only city showing the situation of extreme cold stress $\left(0^{\circ} \mathrm{C}<\mathrm{PET}<4^{\circ} \mathrm{C}\right)$ in January; the remaining winter season is dominated by the cold stress $\left(4^{\circ} \mathrm{C}<\mathrm{PET}<8^{\circ} \mathrm{C}\right)$. PET bioclimate diagram of Constantine could help enormously for an objective explanation of different climate sensations along the year. Since PET for different grades of thermal perception has been derived by calculating PMV in parallel to PET applying the values of the PET reference person to PMV, this has enabled PET to be linked to the ASHRAE 7point scale of thermal sensation via PMV [46]. Thus, PETderived thermal sensations do not account for the seasonal variations in neutral temperature of the native Algerian population as derived by Benharkat and Rouag-Saffidine [45]. Their results for Constantine may be transferred via PET to other climates of the regions. Otherwise, tourists with their short-time stay in the country are not adapted to the seasonal climatic variations of Algeria and, thus, their thermal sensation may be closer to that of the ASHRAE scale and will require measures of climate control which may differ from the demand of the native population.

The geographical factors would control the PET distribution and intensity in Algeria. This phenomenon was also indicated by Rasilla et al. [47], where the dependence of PET in the Iberian Peninsula on some geographical controls (e.g., topography, latitude, and distance to sea) results in marked variation between the values calculated for different stations. The low/middle-altitude continental stations (e.g., Madrid and Seville) show much higher thermal stress than coastal stations (Barcelona and Malaga) or stations in elevated areas. As air temperatures are the result of the influence of altitude which is responsible for milder air temperatures by the decrease in minimum air temperatures and the strong attenuation of the maximum air temperatures, this factor (altitude) could play a key role in moderating the climate of Tamanrasset despite its location in the great Sahara; as a consequence, the number of very hot days $\left(\mathrm{PET}>41^{\circ} \mathrm{C}\right)$ during the summer season in this city is less than that in Béchar.

With no day with very hot thermal perception (PET > $41^{\circ} \mathrm{C}$ ) for Oran to rarely for Algiers, the bioclimate in these two cities is greatly influenced by their proximity to the Mediterranean Sea, a primary factor responsible for reducing extreme heat stress conditions during the summer or the cold stress in the winter. This role could be very remarkable like at Funchal (Madeira, Portugal), where shore sites offer some comfort during hot days as discussed by Lopes et al. [48].
Harzallah et al. [49] evoke the warming of sea and air masses which has led to both positive and negative effects on the potential tourist attractiveness of Djerba in the southern Gulf of Gabès (Tunisia). Based on the calculation of the Daily Climate-Tourism Potential Index (DCTPI) which evaluates climate as a resource for tourism activity based on daily air temperature (mean, minimum, and maximum), precipitation, relative humidity, and wind speed [18], it was demonstrated that higher air temperatures have extended the tourist season. In winter, the region has become more attractive through an increased number of highly favorable days. However, the frequency of very hot days has increased and the total number of days favorable for tourism has declined particularly in summer. As a measure of adaptation to climate change, the experience of Djerba in Tunisia would serve as an example also for the decision-makers in Algeria in order to benefit from the extension of the comfortable bioclimate duration due to the increase of the air temperature to develop the tourism industry outside the summer season.

Considering the climate change context, Working Group I of the Intergovernmental Panel on Climate Change (IPCCWG I) revealed in its fifth assessment report for RCP 8.5 scenario emission [24] an increase in the projected air temperature for Algeria as well as the north African countries of 2 to $3^{\circ} \mathrm{C}$ for the mid-term period (2046-2065) and of 3 to $6^{\circ} \mathrm{C}$ for the long-term period (2081-2100) with respect to a baseline period of 1986-2005. Thus, the effects of global warming would be felt most acutely through the increase in extremes air temperatures which would intensify the occurrence of extreme events and heat stress conditions. As a consequence of that, the Algerian coastal zone will continue to be more attractive when the number of tourists (international and domestic) is expected to reach in 2025 more than 12 million [50]. In this regard, according to Matzarakis et al. [10], the Mediterranean region as well as Italy will experience severe thermal stress conditions during summer, for the "business as usual" emission IPCC scenarios for the period of 2070-2100 relatively to the baseline period of 1961-1990.

The PET was used as indicator for impacts of climate change on thermal comfort of humans on global scale based on general circulation models integrated with different IPCC emission scenarios [51]. However, the temporal resolution of the generated simulated PET maps differs from the one used in this study.

In the future, the use of modified PET (mPET) [52] for better inclusion of humidity conditions for humans will be necessary to refine the obtained results. For Algeria, the differences between mPEt and PET are low because of the aridity of the largest part of the country.

Economically, an additional aspect, which could be induced by the projected warmer climate, is the energy demands. Angeles et al. [53] revealed that, to maintain ideal indoor building conditions at the end of the twenty-first century in the Intra-Americas region, an increased energy production and improved energy infrastructure will be required.

\section{Conclusion}

Algeria offers strongly differing regional climatic conditions not only on an annual scale but also on a seasonal temporal 
scale. Assessing the climatic conditions by PET delivers more appropriate information on the thermal perception of the bioclimate by humans than the air temperature alone. The 10day frequency distribution of PET classes over the different selected cities provides a very high temporal resolution and enables especially favorable and less appropriate bioclimatic phases in the course of the year to be identified. The extension of such studies to further potential sites of Algeria would support the promotion of tourism and recreational activities and assist decision-makers, central and local planners, and stakeholders in different sectors, especially tourism and health.

The winter season exhibits the most favorable conditions for the Saharan sites with only slightly warm conditions. The intermediate seasons give a competitive edge for the two northern cities (Oran and Algiers) and to a lesser degree the inland zone. Considering thermal perception and also the physiological stress for the human organism, the summer season is the most difficult particularly in the desert and, even though not as rigorous, in the inland too. This uncomfortable situation in the summer season is less pronounced in the Mediterranean zone of the country, especially immediately at the coast, and it explains the intensive domestic tourism during this season.

The most important components of thermal perception are humidity and wind.

The most important components of thermal perception are radiation, humidity, and wind. In addition, the water vapor in the atmosphere affects the capacity of the human body to cool down through thermoregulatory processes (i.e., transpiration), and the wind speed can reduce the thermal stress perception [26]. The annual mean relative humidity is approximately 56\% in Algiers and Oran and 50\% in Constantine. Blowing at near $3.0 \mathrm{~m} / \mathrm{s}$ faster on average annually in Oran and Algiers than in Constantine, the wind speed is playing a key role in reducing thermal stress conditions in the coastal cities (sea breezes). However, Tamanrasset and Béchar have, respectively, 13 and $27 \%$ annual average relative humidity. The annual average wind speed difference between these two cities is in favor of Tamanrasset with $2 \mathrm{~m} / \mathrm{s}$. The annual mean temperature difference (influenced remarkably by the cold winter in Béchar) between these two cities is a major factor affecting the PET intensity $\left(32.6^{\circ} \mathrm{C}\right.$ for Béchar and $33.9^{\circ} \mathrm{C}$ for Tamanrasset).

For Algeria, the signal of climate change has now emerged. The amplification of the magnitude, duration, and frequency of extreme heat events recorded in the five cities confirms the situation found for Europe and Italy by Matzarakis et al. [10].

The projected extreme hot climate conditions in addition to the rapid urban expansion will be complicating factors for the Algerian fragile coastal area, particularly in the summer. This would generate adverse social, economic, and environmental effects.

This study and its extension to other Algerian cities may help to mitigate the risks linked to climate change. The climate dimension should be given a priority in the development of any future socioeconomic activity for Algeria.

\section{Conflicts of Interest}

The authors declare that they have no conflicts of interest.

\section{References}

[1] K. Büttner, "Physikalische Bioklimatologie, Akademische, Verlagsgesellschaft Leipzig," 1938.

[2] A. Matzarakis, F. Rutz, and H. Mayer, "Modelling radiation fluxes in simple and complex environments-application of the RayMan model," International Journal of Biometerology, vol. 51, no. 4, pp. 323-334, 2007.

[3] A. P. Gagge, A. P. Fobelets, and L. G. Berglund, "A standard predictive index of human response to the thermal environment," ASHRAE Transactions, vol. 92, pp. 709-731, 1986.

[4] G. Jendritzky, R. de Dear, and G. Havenith, "UTCI-why another thermal index?" International Journal of Biometerology, vol. 56, no. 3, pp. 421-428, 2012.

[5] P. Bröde, D. Fiala, K. Blazejczyk et al., "Deriving the operational procedure for the Universal Thermal Climate Index (UTCI)," International Journal of Biometerology, vol. 56, no. 3, pp. 481494, 2012.

[6] H. Staiger, G. Laschewski, and A. Grätz, "The perceived temperature-a versatile index for the assessment of the human thermal environment. Part A: scientific basics," International Journal of Biometerology, vol. 56, no. 1, pp. 165-176, 2012.

[7] P. Höppe, “The physiological equivalent temperature-a universal index for the biometeorological assessment of the thermal environment," International Journal of Biometerology, vol. 43, no. 2, pp. 71-75, 1999.

[8] H. Mayer and P. Höppe, "Thermal comfort of man in different urban environments," Theoretical and Applied Climatology, vol. 38, no. 1, pp. 43-49, 1987.

[9] A. Matzarakis, H. Mayer, and M. G. Iziomon, "Applications of a universal thermal index: physiological equivalent temperature," International Journal of Biometerology, vol. 43, no. 2, pp. 76-84, 1999.

[10] A. Matzarakis, T. Georgiadis, and F. Rossi, "Thermal bioclimate analysis for Europe and Italy," Il Nuovo Cimento C, vol. 30, no. 6, pp. 623-632, 2007.

[11] VDI, “VDI, 3787, Part I: Environmental Meteorology, Methods for the Human Biometeorological Evaluation of Climate and Air Quality for the Urban and Regional Planning at Regional Level. P art I: Climate, Beuth, Berlin, Germany," 1998.

[12] A. Matzarakis, "Weather- and climate-related information for tourism," Tourism and Hospitality Planning \& Development, vol. 3, no. 2, pp. 99-115, 2006.

[13] A. Matzarakis, "Climate change: temporal and spatial dimension of adaptation possibilities at regional and local scale," in Tourism and the implications of Climate Change: Issues and Actions, C. Schott, Ed., vol. 3 of Bridging Tourism Theory and Practice, pp. 237-259, Emerald Group Publishing, 2010.

[14] K. Zaninović and A. Matzarakis, "The bioclimatological leaflet as a means conveying climatological information to tourists and the tourism industry," International Journal of Biometerology, vol. 53, no. 4, pp. 369-374, 2009.

[15] T.-P. Lin and A. Matzarakis, "Tourism climate and thermal comfort in Sun Moon Lake, Taiwan," International Journal of Biometerology, vol. 52, no. 4, pp. 281-290, 2008.

[16] Y. Djellouli and P. Daget, "Climat et flore dans les steppes du sud-ouest algérien," Bulletin de la Société Botanique de France. Lettres Botaniques, vol. 134, no. 4-5, pp. 375-384, 1987.

[17] M. Tabet-Aoul, Climat et santé, Stress confort au MaghrebMéthodologie, vol. 1 of Edition Benmerabet Bibliographie, 2014. 
[18] L. Henia and T. Alouane, "Le potentiel Climato-touristique de la Tunisie," in Actes du XXème Colloque de l'Association de Climatologie, pp. 27-33, Carthage, Tunisia, 2007.

[19] F. Ali-Toudert and H. Mayer, "Numerical study on the effects of aspect ratio and orientation of an urban street canyon on outdoor thermal comfort in hot and dry climate," Building and Environment, vol. 41, no. 2, pp. 94-108, 2006.

[20] F. Ali-Toudert, M. Djenane, R. Bensalem, and H. Mayer, "Outdoor thermal comfort in the old desert city of Beni-Isguen, Algeria," Climate Research, vol. 28, no. 3, pp. 243-256, 2005.

[21] A. Matzarakis, "Transfer of climate data for tourism applications-the climate-tourism/transfer-information-scheme," Sustainable Environment Research, vol. 24, no. 4, pp. 273-280, 2014.

[22] M. D. Agnew, C. M. Goodess, D. Hemming et al., "Regional Assessment of Climate Change in the Mediterranean," in Case Studies, A. Navarra and L. Tubiana, Eds., vol. 3, pp. 23-60, Springer, 2013.

[23] S. Sahabi-Abed, M. Senouci, M. Haouari, and Z. M. Taleb, "future climate and impacts in the coastal case studies: Gulf of Oran, Algeria, Information sheet, CIRCE project," 2011.

[24] Intergovernmental Panel on Climate Change, Climate Change 2013-The Physical Science Basis. Contribution of Working Group I to the Fifth Assessment Report of the Intergovernmental Panel on Climate Change, T. F. Stocker, D. Qin, and G.-K. Plattner, Eds., Cambridge University Press, Cambridge, UK, 2013.

[25] ANDT, "Schéma Directeur d’Aménagement Touristique (SDAT, 2025), Livre 2: Le plan stratégique : les cinq dynamiques et les programmes d'actions touristiques prioritaires, Agence National de Développement du Tourisme (ANDT), Ministère de l'Aménagement du Territoire, de l'Environnement et du Tourisme," 2008.

[26] H. Mayer, "Urban bioclimatology," Experientia, vol. 49, no. 11, pp. 957-963, 1993.

[27] A. Matzarakis, F. Rutz, and H. Mayer, "Modelling radiation fluxes in simple and complex environments: basics of the RayMan model," International Journal of Biometerology, vol. 54, no. 2, pp. 131-139, 2010.

[28] J. Chatonnet and M. Cabanac, "The perception of thermal comfort," International Journal of Biometerology, vol. 9, no. 2, pp. 183-193, 1965.

[29] IUPS, "Glossary of terms for thermal physiology, third edition revised by the commission for thermal physiology of the international union of physiological sciences," Journal of Thermal Biology, vol. 28, no. 1, pp. 75-106, 2003.

[30] A. Matzarakis and H. Mayer, "Another kind of environmental stress: thermal stress," WHO Collaborating Centre for Air Quality Management and Air Pollution Control NEWSLETTERS, no. 18, pp. 7-10, 1996.

[31] M. Kottek, J. Grieser, C. Beck, B. Rudolf, and F. Rubel, "World map of the Köppen-Geiger climate classification updated," Meteorologische Zeitschrift, vol. 15, no. 3, pp. 259-263, 2006.

[32] L. Bounoua, A. Safia, J. Masek, C. Peters-Lidard, and M. L. Imhoff, "Impact of urban growth on surface climate: a case study in Oran, Algeria," Journal of Applied Meteorology and Climatology, vol. 48, no. 2, pp. 217-231, 2009.

[33] V. K. C. Venema, O. Mestre, E. Aguilar et al., "Benchmarking homogenization algorithms for monthly data," Climate of the Past, vol. 8, no. 1, pp. 89-115, 2012.

[34] O. Mestre, P. Domonkos, F. Picard et al., "HOMER: a homogenization software-methods and applications," IDÖJÁRÁS,
Quarterly Journal of the Hungarian Meteorological Service, vol. 117, no. 1, pp. 47-67, 2013.

[35] Á. Gulyás, J. Unger, and A. Matzarakis, "Assessment of the microclimatic and human comfort conditions in a complex urban environment: modelling and measurements," Building and Environment, vol. 41, no. 12, pp. 1713-1722, 2006.

[36] A. Matzarakis, M. de Rocco, and G. Najjar, “Thermal bioclimate in Strasbourg-the 2003 heat wave," Theoretical and Applied Climatology, vol. 98, no. 3-4, pp. 209-220, 2009.

[37] I. Charalampopoulos, I. Tsiros, A. Chronopoulou-Sereli, and A. Matzarakis, "Analysis of thermal bioclimate in various urban configurations in Athens, Greece," Urban Ecosystems, vol. 16, no. 2, pp. 217-233, 2013.

[38] D. Fröhlich and A. Matzarakis, "Modeling of changes in thermal bioclimate: examples based on urban spaces in Freiburg, Germany," Theoretical and Applied Climatology, vol. 111, no. 3-4, pp. 547-558, 2013.

[39] P. T. Nastos and A. Matzarakis, "Human bioclimatic conditions, trends, and variability in the athens university campus, Greece," Advances in Meteorology, vol. 2013, Article ID 976510, 8 pages, 2013.

[40] C. Ketterer and A. Matzarakis, "Human-biometeorological assessment of the urban heat island in a city with complex topography - the case of Stuttgart, Germany," Urban Climate, vol. 10 , no. 3, pp. 573-584, 2014.

[41] L. Martinelli, T.-P. Lin, and A. Matzarakis, "Assessment of the influence of daily shadings pattern on human thermal comfort and attendance in Rome during summer period," Building and Environment, vol. 92, pp. 30-38, 2015.

[42] P. T. Nastos and I. D. Polychroni, "Modeling and in situ measurements of biometeorological conditions in microenvironments within the Athens University Campus, Greece," International Journal of Biometerology, vol. 60, no. 10, pp. 1463-1479, 2016.

[43] A. De Bono, G. Giuliani, S. Kluser, and P. Peduzzi, "Impacts of summer 2003 heat wave In Europe," in Environment Alert Bulletin, United Nations Environment Programme, DEWA/GRIDEurope, 2004.

[44] P. K. Sen, "Estimates of the regression coefficient based on Kendall's tau," Journal of the American Statistical Association, vol. 63, pp. 1379-1389, 1968.

[45] S. Benharkat and D. Rouag-Saffidine, "Approche adaptative du confort thermique dans les espaces d'enseignement universitaire à Constantine (Algérie)," Nature and Technology, vol. 14, pp. 19-28, 2016.

[46] H. Mayer, A. Matzarakis, and S. Linser, "Thermischer Wirkungskomplex der Waldatmosphäre," Annual Meteorologie, vol. 33, pp. 34-39, 1997.

[47] Á. D. Rasilla and G. F. Fernandez, "An assessment of heat stress in the Iberian Peninsula," EMS Annual Meeting Abstracts, vol. 7, EMS2010-380, 2010.

[48] A. Lopes, S. Lopes, A. Matzarakis, and M. J. Alcoforado, “The influence of the summer sea breeze on thermal comfort in funchal (Madeira). A contribution to tourism and urban planning," Meteorologische Zeitschrift, vol. 20, no. 5, pp. 553-564, 2011.

[49] A. Harzallah, B. M. Nejmeddine, and S. Ben-Salem, Information Sheet on Future Climate and impacts in the coastal case studies: Gulf of Gabès, Tunisia, CIRCE project, 2011.

[50] A. Magnan, "Le tourisme littoral en Méditerranée, tendances et perspectives face au changement climatique," IDDRI, 2009. 
[51] A. Matzarakis and B. Amelung, "Physiological equivalent temperature as indicator for impacts of climate change on thermal comfort of humans," in Seasonal Forecasts, Climatic Change and Human Health, M. Thomson, R. Garcia-Herrera, and M. Beniston, Eds., vol. 30 of Advances in Global Change Research, pp. 161-172, Springer-Sciences and Business Media, 2008.

[52] Y. Chen and A. Matzarakis, "Modified physiologically equivalent temperature-basics and applications for western European climate," Theoretical and Applied Climatology, pp. 1-15, 2017.

[53] M. E. Angeles, J. E. González, and N. Ramírez, "Impacts of climate change on building energy demands in the intra-Americas region," Theoretical and Applied Climatology, pp. 1-14, 2017. 

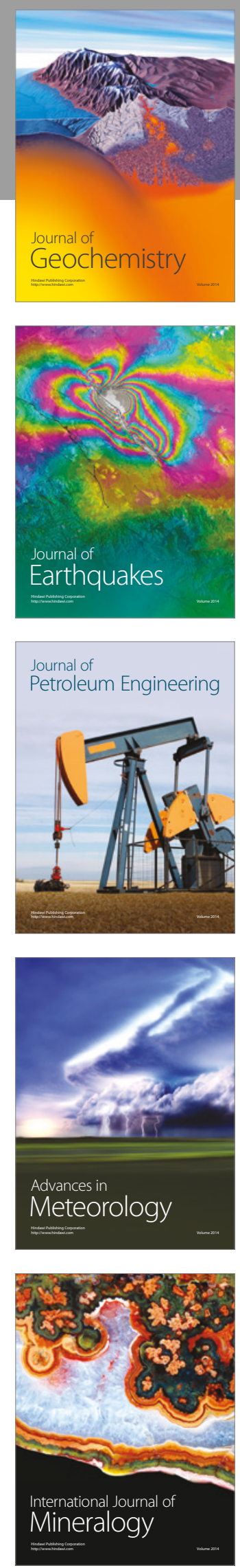
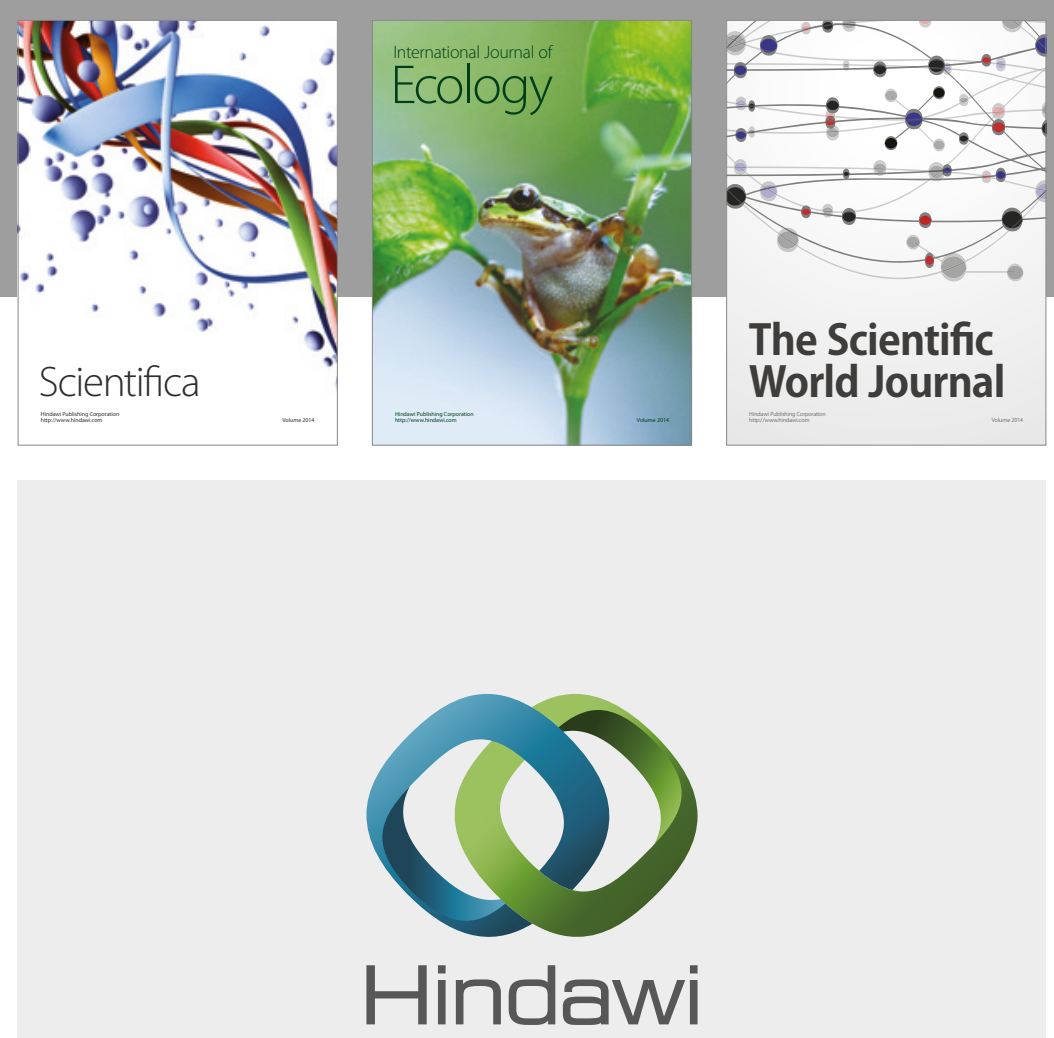

Submit your manuscripts at

https://www.hindawi.com
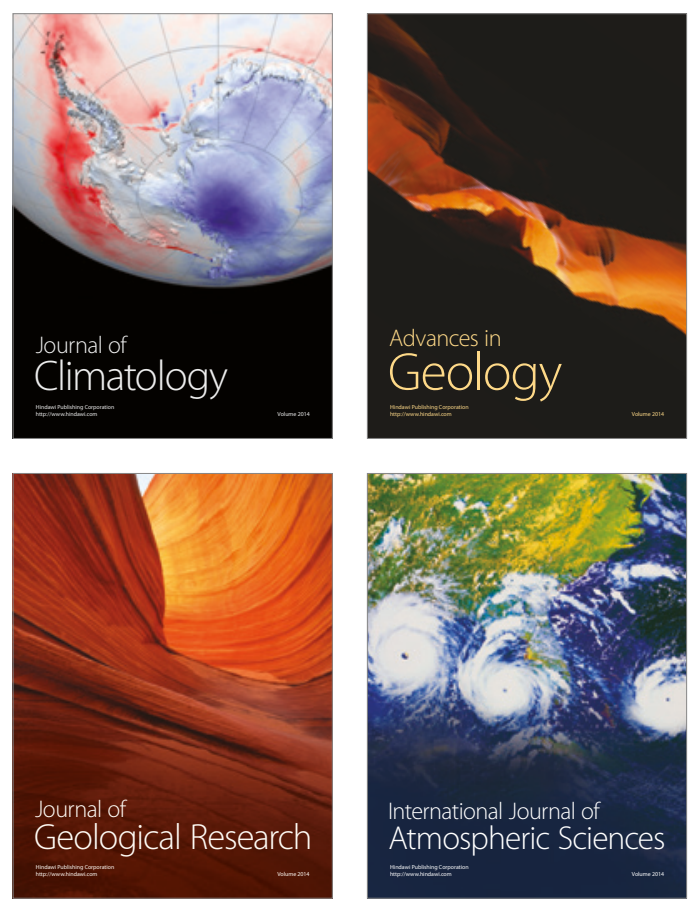

The Scientific

World Journal
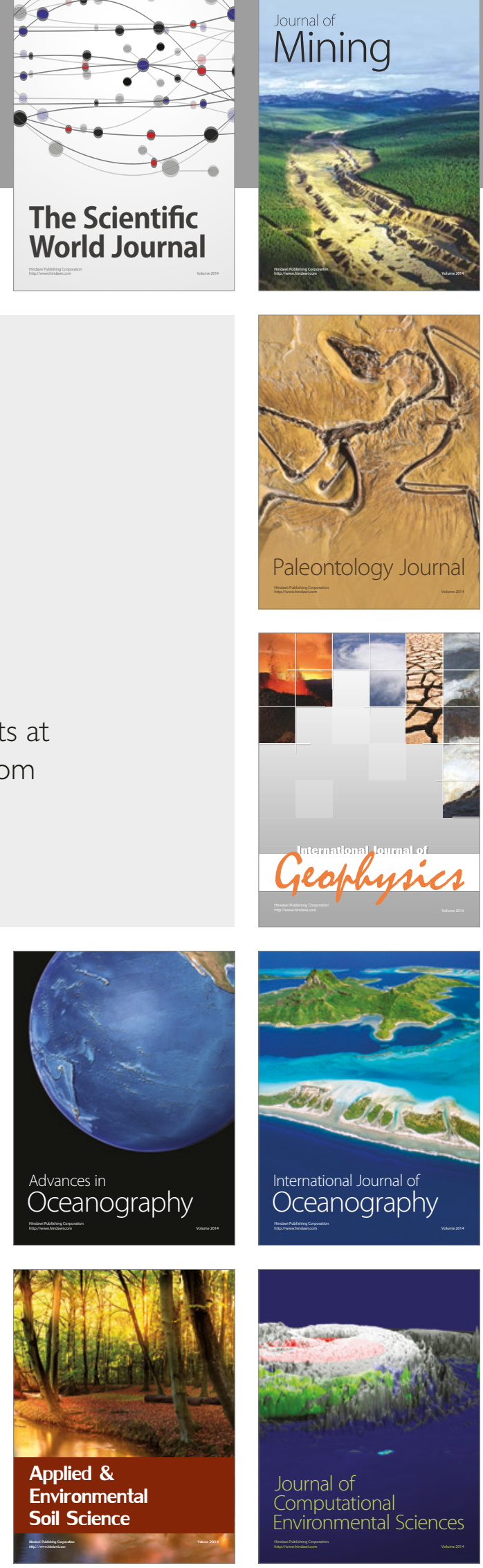